\title{
Uterine clinical findings, fertility rate, leucocyte migration, and COX-2 protein levels in the endometrial tissue of susceptible mares treated with platelet-rich plasma before and after AI
}

\author{
Lorenzo G. Segabinazzi a , Aime M. Friso a , Sebastian B. Correal ${ }^{\text {, }}$, André M. Crespilho ${ }^{\text {b, c }}$, \\ José Antonio Dell'Aqua Jr. a, Jordi Miró d, Frederico O. Papa a , Marco Antonio Alvarenga a, * \\ ${ }^{a}$ Department of Animal Reproduction and Veterinary Radiology, São Paulo State University - UNESP, Botucatu, Brazil \\ b Santo Amaro University, UNISA, São Paulo, Brazil \\ c Severino Sombra University, Vassouras, Rio de Janeiro, Brazil \\ ${ }^{\mathrm{d}}$ Equine Reproduction Service, Department of Animal Medicine and Surgery, Faculty of Veterinary Medicine, Autonomous University of Barcelona, Spain
}

\section{A R T I C L E I N F O}

\section{Article history:}

Received 27 February 2017

Received in revised form

3 August 2017

Accepted 3 August 2017

Available online 12 August 2017

\section{Keywords:}

Endometritis

Equine

Embryo transfer

Platelet-rich plasma

\begin{abstract}
A B S T R A C T
Persistent mating-induced endometritis (PMIE) results in decreased fertility in horses, thereby causing a significant impact in the horse market. Platelet-rich plasma (PRP), a modulator of the inflammatory response, has been largely used in veterinary medicine. Here, we investigated the effects of PRP on uterine inflammation, conception rate, endometrial polymorphonuclear neutrophil (PMN) migration, and COX-2 protein levels in the endometrial tissue. Thirteen PMIE-susceptible mares were used for artificial insemination (AI). The mares were inseminated with fresh semen in three consecutive cycles in a cross-over study design. The following cycle classifications were used: control cycle, no pharmacological interference; pre-AI, $20 \mathrm{~mL}$ of PRP was infused $24 \mathrm{~h}$ before $\mathrm{AI}$; and post-AI, $20 \mathrm{~mL}$ of PRP was infused four $\mathrm{h}$ after AI. Follicular dynamics were monitored daily by transrectal ultrasound. When a follicle larger than $35 \mathrm{~mm}$ was detected, ovulation was induced with deslorelin acetate $(1 \mathrm{mg}$, im). AI was performed $24 \mathrm{~h}$ after ovulation induction. Intrauterine fluid (FLU) was evaluated by ultrasonography before and $24 \mathrm{~h}$ after AI. PMNs in uterine cytology (CYT) and biopsy (HIS) were also observed before and $24 \mathrm{~h}$ after Al. Pregnancy was determined within 14 days after ovulation. Number of COX-2 positive cells was evaluated by immunohistochemistry. Both PRP treatments resulted in a decrease of PMNs in the CYT after breeding when compared to controls. FLU did not differ between cycles; however, the conception rates were significantly higher in the PRP mares. Mares positive for endometritis decreased in both treatment groups, and a more intense positive COX-2 labeling was observed in the control group when compared to the two treatment groups. In conclusion, PRP beneficially reduces inflammatory response in PMIE mares independent of when treatments were administered, thus increasing chances of successful pregnancy.
\end{abstract}

() 2017 Elsevier Inc. All rights reserved.

\section{Introduction}

Platelet-rich plasma (PRP) is whole blood plasma with a high platelet concentration, and contains diverse growth factors that can act in injured tissue by mitogenic, neovascular, and antiinflammatory effects [1-4]. After the platelets are activated,

\footnotetext{
* Corresponding author. Departamento de Reprodução Animal e Radiologia Veterinária, FMVZ, UNESP, Distrito de Rubião Junior, s/nº, 18618-970 Botucatu, SP, Brazil.

E-mail address: malvarenga@fmvz.unesp.br (M.A. Alvarenga).
}

growth factors are released in the injured area, altering the chemotactic gradient and reducing leucocyte attraction to inflamed tissue [5,6]. Studies have also shown in mares with uterine inflammation treated with PRP a downregulation of intrauterine inflammatory $[7,8]$.

Uterine inflammation is a physiological process that occurs after artificial insemination (AI) or natural breeding to clear excess semen and microorganisms from uterine lumen [9]. Mares that are considered resistant to persistent mating-induced endometritis (PMIE) are able to reduce this inflammatory process within 12-24 h [10] However, mares that are unable to do it are classified 
as susceptible to PMIE. Susceptible mares shows excessive amount of polymorphonuclear neutrophil (PMNs) and fluid accumulation inside the uterus [11-13]. Additionally, the endometrium of susceptible mares expresses more pro-inflammatory cytokines and less anti-inflammatory cytokines to regulate acute inflammation when compared to resistant mares [14-17].

Furthermore, the acute inflammatory process begins after bacterial or semen recognition by the Toll-like receptors (TLRs) in the endometrial cells $[14,15,18-23]$. After activation of the TLRs, nuclear factor-kappa B $(\mathrm{NF}-\kappa \mathrm{B})$ is expressed, thereby activating proinflammatory cytokines, chemokines, and cyclooxygenase-2 (COX-2) $[24,25]$. These molecules regulate the inflammatory signals to the immune cells $[15,26]$.

Finally, usually used endometritis therapies could be consider supporting treatments since they aim to reduce the predisposing factors instead of acting in the inflammatory process directly. Additionally, immunomodulators have been used to modulate the uterine inflammatory process $[13,14,27,28]$. The PRP acts by inhibiting NF- $\kappa \mathrm{B}$, and is capable of downregulating pro-inflammatory cytokines in mares endometrium $[29,30]$. Therefore, here we investigated the effects of PRP on uterine inflammation, conception rate, endometrial PMN migration, and COX-2 protein levels in the endometrial tissue. Furthermore, we either assessed for the optimal time to use the PRP treatment, either pre- or post-AI.

\section{Material and methods}

This study was approved by the Animal Care and Use Committee of São Paulo State University.

Thirteen crossbred mares from the Department of Animal Reproduction and Veterinary Radiology of São Paulo State University, with ages ranging from 8 to 20 years old were chosen based on reproductive histories. These animals exhibited following characteristics: presence of fluid accumulation $24 \mathrm{~h}$ after AI $(>10 \mathrm{~mm}$ of fluid column), exacerbated number of neutrophil cells (>20\%) $48 \mathrm{~h}$ after $\mathrm{AI}$ as determined via uterine cytology, and poor embryo recovery rates $(<30 \%)$. The mares were maintained in similar handling and pasture, and they received $10 \mathrm{~kg}$ of silage, water, and mineral salt ad libitum.

Before starting the study, a breeding soundness examination was performed to confirm that all of the experimental mares had a negative uterine culture, negative cytology ( $<5 \%$ of PMNs) [31], and no free fluid into the uterine lumen.

\subsection{Detecting the estrous cycle and treatment protocol}

Mares were examined by transrectal palpation and ultrasonography (Sono Scape A5V, Domed, SP, Brazil) daily. When a follicle measuring $\geq 35 \mathrm{~mm}$ and an endometrial edema of at least grade 2 was diagnosed (min. grade 0; max. grade 4) [32], an intramuscular injection of $1 \mathrm{mg}$ of deslorelin acetate (Sincrorelin, Ouro Fino, Brazil) was performed to induce ovulation. Artificial inseminations with fresh semen $\left(800 \times 10^{6}\right.$ total spermatozoa) were performed $24 \mathrm{~h}$ after ovulation induction.

Three cycles of each mare were used and randomly assigned to control and treated groups in a crossover study. In the control cycle group, the mares had no intrauterine infusion. In the treated group, $20 \mathrm{~mL}$ of PRP was infused with an insemination pipette (pipette to mares, Provar Comercial LTDA, SP, Brazil) inserted into the uterine body. The treatments differed by the time of infusion: pre-AI treatment consisted of $20 \mathrm{~mL}$ of PRP infused $24 \mathrm{~h}$ before AI at the same time ovulation was induced, and post-AI treatment consisted of $20 \mathrm{~mL}$ of PRP infused $4 \mathrm{~h}$ after AI.

The perineum was cleaned using a mild detergent, rinsed with clean water, and dried with paper towels. For the intrauterine procedures, sterilized materials were used to minimize contaminations. Mares received only one treatment per estrous cycle.

\subsection{Semen collection}

Semen from only one stallion was used for all inseminations. An artificial vagina Botucatu Model (Botupharma, Botucatu/SP, Brazil) was used to semen collections. Gel fractions were removed using a nylon filter. The sperm concentration was measured using a Neubauer chamber, and the sperm motility was measured by computerized analysis (Hamilton Thorne Research, Danvers, USA). The semen was diluted to a concentration of 50 million sperms per $\mathrm{mL}$ using a skimmed milk-based extender (Botu-semen, Botupharma, Botucatu, SP, Brazil). An AI dose of total 1 billion sperm was used.

\subsection{PRP preparation}

PRP was prepared by a single centrifugation. In brief, $45 \mathrm{~mL}$ of blood samples were collected from each animal through a puncture of the external jugular vein and conditioned into tubes containing 3.2\% sodium citrate (Vacutainer, Labor Import, SP, Brazil). Blood samples were homogenized and accommodated in an isothermal box for $1 \mathrm{~h}$. Subsequently, samples were centrifuged at $120 \mathrm{xg}$ for $10 \mathrm{~min}$. From each centrifuged tube, the top half layer of the plasma was discarded and the remaining fraction was used as PRP. The tubes with PRP were placed in an isothermal box (Botuflex, Botupharma, Botucatu/SP, Brazil) to be maintained at a controlled temperature between $20{ }^{\circ} \mathrm{C}$ and $25{ }^{\circ} \mathrm{C}$ for $1 \mathrm{~h}$ until uterine infusion.

The platelet concentration was measured using a hemocytometer chamber. The minimum platelet concentration used for the treatment was 250,000 platelets/mL, and the PRP was used without activation as previously described [33].

\subsection{Sampling strategy}

\subsubsection{Intrauterine fluid evaluation}

Transrectal ultrasound evaluations were performed $24 \mathrm{~h}$ before and after AI, and the presence or absence of fluid was recorded. If fluid was present, the height and width of the intrauterine fluid column was measured in the bifurcation region of the uterine horn. The amount of uterine fluid was quantified using the height and width multiplication $\left(\mathrm{mm}^{2}\right)$.

\subsubsection{Endometrial exfoliative cytology}

Endometrial exfoliative cytology was performed $24 \mathrm{~h}$ before and after AI. The samples were obtained using a disposable cytobrush (cytological disposable collector for mares, Provar Commercial LTDA, SP, Brazil) as previously described [34]. After the collection, the slides were air-dried and stained by Dip Quick (Instant Prov; NewProv, Brazil). The samples were then microscopically examined under a 1000X oil immersion objective, and the percentage of PMNs was randomly determined. Cytological samples were classified as either lacking inflammation $(<5 \%)$, mild inflammation $(5-<15 \%)$; moderate inflammation $(\geq 15-<30 \%)$; and severe inflammation $(\geq 30 \%)$ as described previously [31].

\subsubsection{Conception rates}

Ultrasound examinations were performed 14 days after ovulation was determined. Mares that did not ovulated $24 \mathrm{~h}$ after AI were excluded and the next cycle was used. After the examination, $5 \mathrm{mg}$ (im) of dinoprost tromethamine (Lutalyse ${ }^{\circledR}$, Zoetis, SP, Brazil) was applied to interrupt the pregnancy. 
Table 1

Platelets and quantification of polymorphonuclear neutrophil in whole blood and platelet-rich plasma.

\begin{tabular}{ll}
\hline Parameters & Average \\
\hline Platelets in blood & $132,740 \pm 24,430 / \mu \mathrm{L}^{\mathrm{a}}$ \\
Platelets in PRP & $354,236 \pm 17,540 / \mu \mathrm{L}^{\mathrm{b}}$ \\
PMNs in blood & $9106 \pm 804.2 / \mu \mathrm{L}^{\mathrm{a}}$ \\
PMNs in PRP & $378 \pm 74.1 / \mu \mathrm{L}^{\mathrm{b}}$ \\
\hline
\end{tabular}

Values are expressed as mean \pm standard deviation. Lines with different superscript $(a, b)$ represent statistically significant differences $(P<0.05)$.

\subsubsection{Endometrial biopsy}

Biopsy samples were collected $24 \mathrm{~h}$ after AI from each mare, and these were taken at the anterior part of the uterine body using a sterilized alligator jaw biopsy forceps (Botupharma, Botucatu, Brazil) covered with a sterile glove. After collection, the biopsy samples were removed and stored in $10 \%$ neutral buffered formalin and embedded in paraffin for histology [35].

Tissue sections were cut at a5 $\mu \mathrm{m}$ thickness and stained with haematoxylin \& eosin (H\&E) [36]. For each sample, five fields without artifacts, intact blood vessels, or damaged epithelium were examined by light microscopy (Primo Star, Zeiss, Brazil) at $400 \times$ magnification. The amount, types, and locations of the PMNs and lymphocytes were recorded, and a 5 fields was calculated. Samples averaging 0 to 17 PMNs in the stratum compactum were classified as negative, and samples with average of $\geq 18$ PMNs were classified as positive for endometritis [37].

\subsection{COX-2 immunohistochemistry}

The amount of COX-2 protein was measured using a standard streptavidin-avidin-biotin immunoperoxidase technique as previously described [38]. Paraffin-embedded sections were deparaffinized and rehydrated. Endogenous peroxidases were inhibited by exposure to $3 \% \mathrm{H}_{2} \mathrm{O}_{2}$ in distilled water for $5 \mathrm{~min}$. Antigen retrieval was performed by heating the tissue to $90-100{ }^{\circ} \mathrm{C}$ in citrate buffer ( $\mathrm{pH} \mathrm{6.0)}$ ) for $10 \mathrm{~min}$, and then cooling to room temperature for $30 \mathrm{~min}$. Non-specific protein binding was blocked using $2 \%$ bovine serum albumin (Sigma-Aldrich, St. Louis, Missouri, USA). The sections were incubated overnight at $4{ }^{\circ} \mathrm{C}$ with a polyclonal rabbit anti-murine COX-2 antibody (Cayman Chemical, Ann Arbor, Michigan, USA) diluted at 1:500, and then washed with PBS three times. The slides were then incubated with biotinylated polyclonal goat anti-rabbit secondary antibody (Dako, Glostrup, Denmark) for $1 \mathrm{~h}$, followed by incubation for $1 \mathrm{~h}$ with an avidin-biotin-peroxidase complex (ImmunoPure, Thermo Fisher Scientific, Rockford, Illinois, USA). The COX- 2 labeling was visualized using 3,3-diaminobenzidine tetrahydrochloride (Sigma-Aldrich, Madrid, Spain) and counterstained with Mayer's haematoxylin. Normal rabbit serum was used as a negative control and canine squamous cell carcinomas were prepared [39] as a positive control.

The number of COX-2 positive cells was evaluated by light microscopy (Primo Star, Zeiss, Brazil) at 400X magnification in five randomly selected fields. A modified scoring system was used to simultaneously record the number, the intensity, and the location of the labeled cells $(0$, negative to COX- $2 ; 1$, mild presence of positive cells; 2 , moderate presence of positive cells; 3 , severe presence of positive cells) as previously described [40].

\subsection{Statistical analyses}

To evaluate the Gaussian distribution: platelets, PMNs and intrauterine fluid columns were evaluated using the KolmogorovSmirnov normality test. ANOVA by Tukey's test was used to

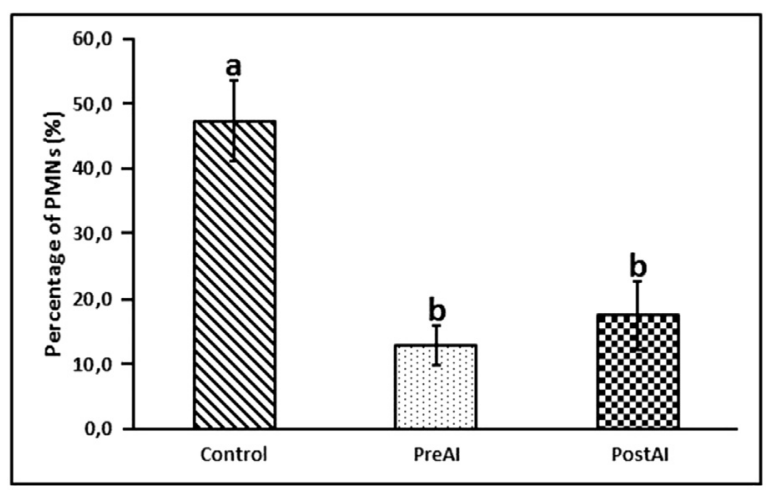

Fig. 1. Percentage of polymorphonuclear cells (PMNs) observed in the uterine exfoliative cytology $24 \mathrm{~h}$ after artificial insemination (AI) in persistent breeding-induced endometritis mares in the non-treated cycle group (control), treated cycle group with platelet-rich plasma $24 \mathrm{~h}$ before $\mathrm{AI}$ (pre-AI), and treated cycle group with PRP $4 \mathrm{~h}$ after AI (post-AI). Columns with different superscript (a, b) represent statistically significant differences $(\mathrm{P}<0.05)$.

compare parametric continuous data. The nonparametric data were tested using Kruskal-Wallis test followed by Dunn's test. The data were primarily subjected to a curve fitting test to determine the best fit for a multiple linear regression model. Conception rate was evaluated by a logistic regression model by considering pregnancy as the dependent variable and the three treatment groups as explanatory variables.

The data of the PMNs from the biopsies and COX-2 immunohistochemical data were evaluated by Shapiro-Wilk test and no normality distribution was found. So, non-parametric Kruskal-Wallis test was used to examine the differences between groups. When significant differences was observed, the corresponding data were rank-transformed and means compared using the Tukey-Kramer test.

Significance was set at $\mathrm{P} \leq 0.05$ for all tests and $\mathrm{P}$ values between 0.05 and 0.1 were considered a statistical trend.

\section{Results}

Mean platelet concentration after PRPs preparation increase 2.6-fold when compared to blood count $(\mathrm{P}<0.05)$. The mean concentration of PMNs in the PRP were 23.9-fold lower than the PMN blood count (Table 1). All samples contained more than 250,000 platelets $/ \mu \mathrm{L}$.

Intrauterine fluid was not present before $\mathrm{AI}$ in any cycle and no significant differences $(P>0.05)$ were observed in the presence of uterine fluid after AI between cycles (C: $893 \pm 292 \mathrm{~mm}^{2}$; pre-AI: $587 \pm 214 \mathrm{~mm}^{2}$; post-AI: $591 \pm 213 \mathrm{~mm}^{2}$ ). A significant increase $(\mathrm{P}<0.05)$ in PMNs was observed in all cycles $24 \mathrm{~h}$ after AI. However, mares in both treated groups showed reduced $(P<0.05)$ PMNs in

Table 2

The number and percentage of mares classified in each endometrial inflammatory score via cytological examination $24 \mathrm{~h}$ after breeding either without pharmacological interference (control), or treated with platelet-rich plasma $24 \mathrm{~h}$ before (pre$\mathrm{AI}$ ) or $4 \mathrm{~h}$ after (post-AI) artificial insemination.

\begin{tabular}{llllll}
\hline \multirow{2}{*}{ Group } & \multicolumn{4}{l}{ Inflammatory score $(\%)$} \\
\cline { 2 - 6 } & Non-inflamed & Mild & Moderate & Severe & TOTAL \\
\hline Control & 0 & $0^{\mathrm{a}}$ & $3(23 \%)$ & $10^{\mathrm{a}}(77 \%)$ & 13 \\
Pre-AI & 0 & $10^{\mathrm{b}}(76.9 \%)$ & $2(15.3 \%)$ & $1^{\mathrm{b}}(7.7 \%)$ & 13 \\
Post-AI & $1(7.7 \%)$ & $8^{\mathrm{b}}(61.5 \%)$ & $1(7.7 \%)$ & $2^{\mathrm{b}}(15.3 \%)$ & 12 \\
\hline
\end{tabular}

Non-inflamed - <5\%; Mild - 5-<15\%; Moderate $-\geq 15-<30 \%$; Severe - $\geq 30 \%$ polymorphonuclear neutrophils via cytology. Columns with different superscript (a, b, c) represent statistically significant differences $(\mathrm{P}<0.05)$. 


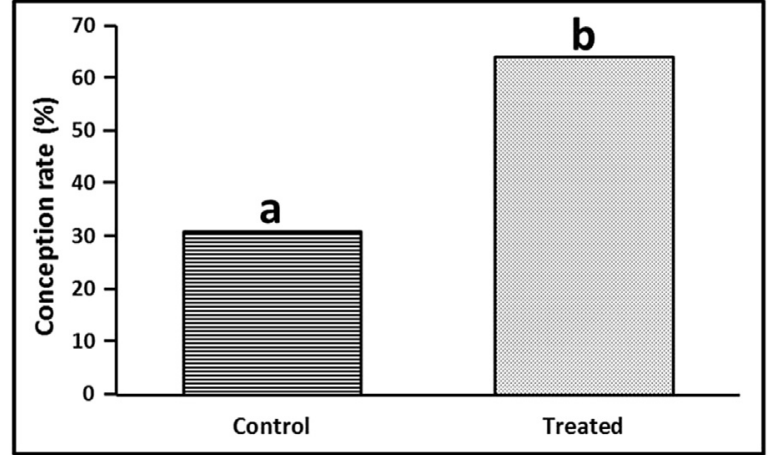

Fig. 2. Conception rate per cycle (\%) in persistent breeding-induced endometritis mares in the non-treated cycle group (control $-n=4 / 13$ ) and platelet-rich plasmatreated (pre-AI $-\mathrm{n}=9 / 13$; and post-AI $-\mathrm{n}=8 / 13$ ) cycle groups (treated). Columns with different superscripts (a, b) represent statistically significant differences $(\mathrm{P}<0.05)$.

cytology (Fig. 1) and inflammatory score (Table 2).

Conception rate did not differ $(P>0.05)$ between groups $(C$ : $31 \%$; pre-AI: $69 \%$; post-AI: $58 \%$ ). However when the treatment was considered a dependent variable, mares with PMIE exhibited a significantly higher $(\mathrm{P}<0.05)$ conception rate after intrauterine PRP infusion compared with the control cycle (Fig. 2).

\subsection{Biopsy}

A diffuse PMN infiltration into the luminal epithelium and stratum compactum was observed in all samples. The mean number of PMNs did not differ in the stratum compactum between control group and post-AI group, but the pre-AI group demontrated a statistical trend $(P=0.063)$ showing a reduction of these cells (Table 3). However, mares classified as positive for endometritis were fewer $(\mathrm{P}<0.05)$ in both the treated groups when compared to control group (Fig. 3). PMNs in the stratum spongiosum was also significantly $(\mathrm{P}<0.05)$ higher in the control cycle than in the treated cycles. Lymphocytes concentration did not differ $(\mathrm{P}>0.05)$ in endometrial biopsies at any cycle (Table 3). Representative images of the biopsies are shown in Fig. 4.

\subsection{Cox-2 immunhistochemistry}

Negative staining for COX-2 was observed in all groups before AI. However, more positive COX- 2 cells were observed $(\mathrm{P}<0.05)$ in the control group compared to both treated groups (Table 4). Fig. 5 shows representative images of the COX-2 immunohistochemistry results for each treatment group.

\section{Discussion}

The average concentration of platelets in the PRP was greater

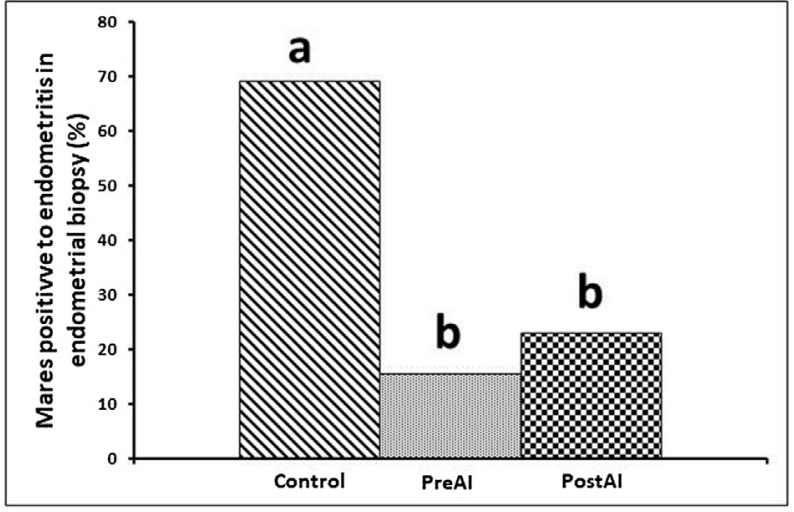

Fig. 3. Percentage of mares positive for endometritis via endometrial biopsies (an average of $\geq 18$ polymorphonuclear neutrophils per field at $400 \times$ magnification) evaluated $24 \mathrm{~h}$ after artificial insemination (AI) in the control cycle group with no intrauterine treatment group $(n=9 / 13)$, pre-AI group that was treated with plateletrich plasma (PRP) $24 \mathrm{~h}$ before $\mathrm{AI}(\mathrm{n}=2 / 13)$, and post-AI group that was treated with PRP $4 \mathrm{~h}$ after AI $(\mathrm{n}=3 / 13)$. Columns with different superscript $(\mathrm{a}, \mathrm{b})$ represent statistically significant differences $(\mathrm{P}<0.05)$.

than the minimum concentration $(300,000$ platelets $/ \mu \mathrm{L})$ recommended by Anitua et al. [41], which also contained 2.6 times more platelets than in the blood [42]. Furthermore, platelet concentrations used in our study was also greater than that used by Reghini et al. [8], but the mares were still successful treated for uterine inflammation. Additionally, our PRP intrauterine infusion protocol was practical and required less blood volume than the previously described protocols [8].

Furthermore, Metcalf et al. [43] and Reghini et al. [8] observed a reduction in intrauterine fluid accumulation in barren mares and mares with chronic degenerative endometritis (CDE), respectively, using intra-uterine PRP treatment. However, in the current study, no statistically significant differences were found for this parameter after PRP treatment. This discrepancy may be due to variability between mares and a higher standard deviation among the results. Some studies $[14,37]$ using immunomodulatory products have also shown similar results where inflammatory markers were modulated without any changes in intrauterine fluid, which may be caused by failures in myometrial contractility or cervical relaxation [44-46].

In our study, both PRP treatments successfully reduced the number of PMNs $24 \mathrm{~h}$ after AI regardless of whether the inflammatory reaction was already triggered (post-AI) or not (pre-AI). Likewise, the number of mares that were classified as susceptible to endometritis decreased significantly when PRP was used. During the inflammatory process, the PRP releases growth factors that were stored in the $\alpha$-granules of the platelets [47,48]. Some of the growth factors that are released after activation in inflamed tissue include TGF- $\beta$, IGF-I, PDGFs, FGFs, EGFs, and VEGFs. All these factors are important for tissue repair due to their mitogenic, antiinflammatory, chemotactic, and neovascular effects [1-4]. The

Table 3

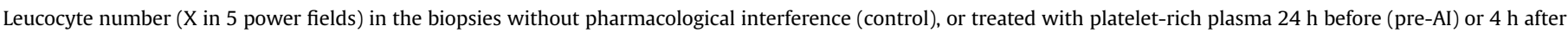
(post-AI) artificial insemination.

\begin{tabular}{|c|c|c|c|c|}
\hline \multirow[t]{2}{*}{ Cycle } & \multicolumn{2}{|l|}{ PMNs } & \multicolumn{2}{|l|}{ Lymphocytes } \\
\hline & Stratum compactum & Stratum spongiosum & Stratum compactum & Stratum spongiosum \\
\hline Control & $22.3 \pm 6.1^{\mathrm{c}}$ & $4.20 \pm 1.45^{\mathrm{a}}$ & $30.61 \pm 6.61$ & $14.96 \pm 3.5$ \\
\hline Pre-AI & $8.9 \pm 2.4^{\mathrm{d}}$ & $0.97 \pm 0.84^{\mathrm{b}}$ & $30.36 \pm 5.90$ & $15.13 \pm 4.21$ \\
\hline Post-AI & $9.7 \pm 2.6^{\mathrm{cd}}$ & $1.06 \pm 0.67^{b}$ & $31.15 \pm 5.41$ & $14.89 \pm 4.50$ \\
\hline
\end{tabular}

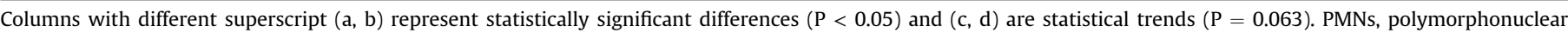
neutrophils. 

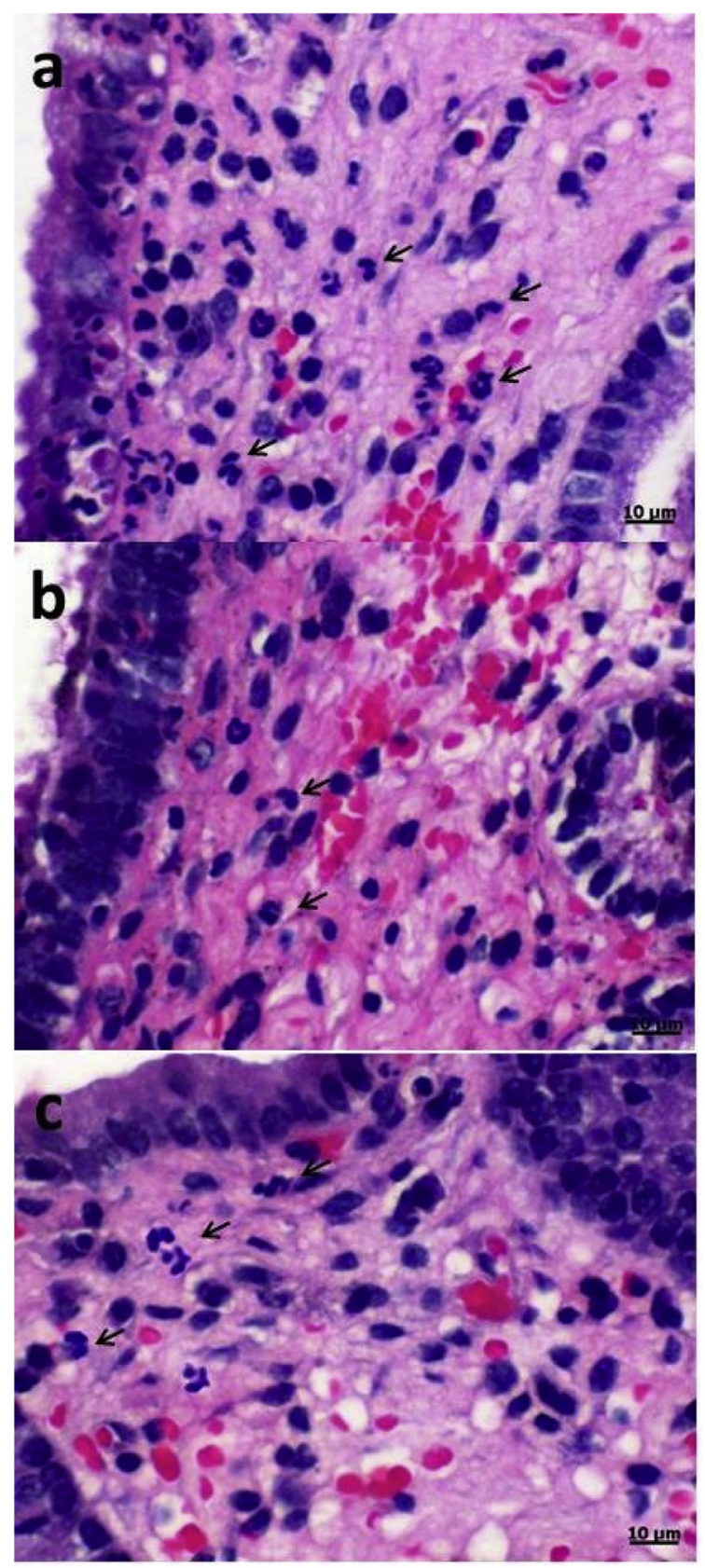

Fig. 4. Representative images of H\&E-stained biopsies showing the inflammatory cell infiltration $24 \mathrm{~h}$ after artificial insemination in the control cycle group (a); pre-AI treated group (b), and post-AI treated group (c). Arrows indicate neutrophils.

capacity of PRP to decrease PMNs numbers as observed in the endometrial exfoliative cytology was shown by Reghini et al. [8] by applying activated PRP in the uterus of mares with CDE after breeding.

We also observed in the biopsies of stratum compactum that the pre-treatment with PRP was more effective in reducing PMN infiltration after AI than the post-AI treatment. The inflammatory reaction was already triggered [49] as suggested by the expression of the pro-inflammatory cytokines [14,15,19-25] when PRP was used $4 \mathrm{~h}$ post-AI. That is probably why PRP use before AI had better effects modulating uterine inflammation. Dexamethasone also reduced the amount of inflammatory markers when used before breeding in mares susceptible to endometritis [13], but no changes in the fertility rate [50] or inflammatory markers [51] were

\section{Table 4}

Median scores for COX-2 immunohistochemical labeling in biopsy samples from mares $24 \mathrm{~h}$ after insemination, and number of mares in each score, without pharmacological interference (control), or treated with platelet-rich plasma $24 \mathrm{~h}$ before (pre-AI) or $4 \mathrm{~h}$ after (post-AI) artificial insemination.

\begin{tabular}{llllll}
\hline Treatment & Score & \multicolumn{4}{l}{ Number of mares (\%) } \\
\cline { 3 - 6 } & & Mild & Moderate & Severe & TOTAL \\
\hline Control & $3 \pm 0,48^{\mathrm{a}}$ & 0 & $4(30.8 \%)$ & $9(69.2 \%)$ & $13(100 \%)$ \\
Pre-AI & $2 \pm 0,37^{\mathrm{b}}$ & $4(15.4 \%)$ & $9(84.6 \%)$ & 0 & $13(100 \%)$ \\
Post-AI & $2 \pm 0,68^{\mathrm{b}}$ & $4(30.8 \%)$ & $5(53.8 \%)$ & $4(15.4 \%)$ & $13(100 \%)$ \\
\hline
\end{tabular}

Columns with different superscript $(a, b, c)$ represent statistically significant differences $(\mathrm{P}<0.05)$

observed when this therapy was used after breeding.

The PRP acts in the inflammation process by inhibiting NF- $\kappa \mathrm{B}$ $[29,30]$, a key valve of the inflammatory process $[30,52,53]$. In addition, PRP increased lipoxin A4 and other chemokines that reduces the attraction of PMNs to the inflamed tissue [5,6]. These effects resutls in downregulation of cytokines, such as TNF- $\alpha$ and IL-1, and COX-2 expression in vitro [4,54-56], and also reduced endometrial expression of IL-1b, IL-6, and IL-8 in susceptible mares in vivo [7].

Additionally, in the present study, an intense expression of COX2 in the endometrium of susceptible mares was observed in the control group; however, after PRP treatment, a lower expression of COX-2 was observed in the endometrium of these mares. COX-2 expression as well as others pro-inflammatory cytokines are regulated by $\mathrm{NF}-\kappa \mathrm{B}$ signaling pathway $[52,53,57]$, and plays an

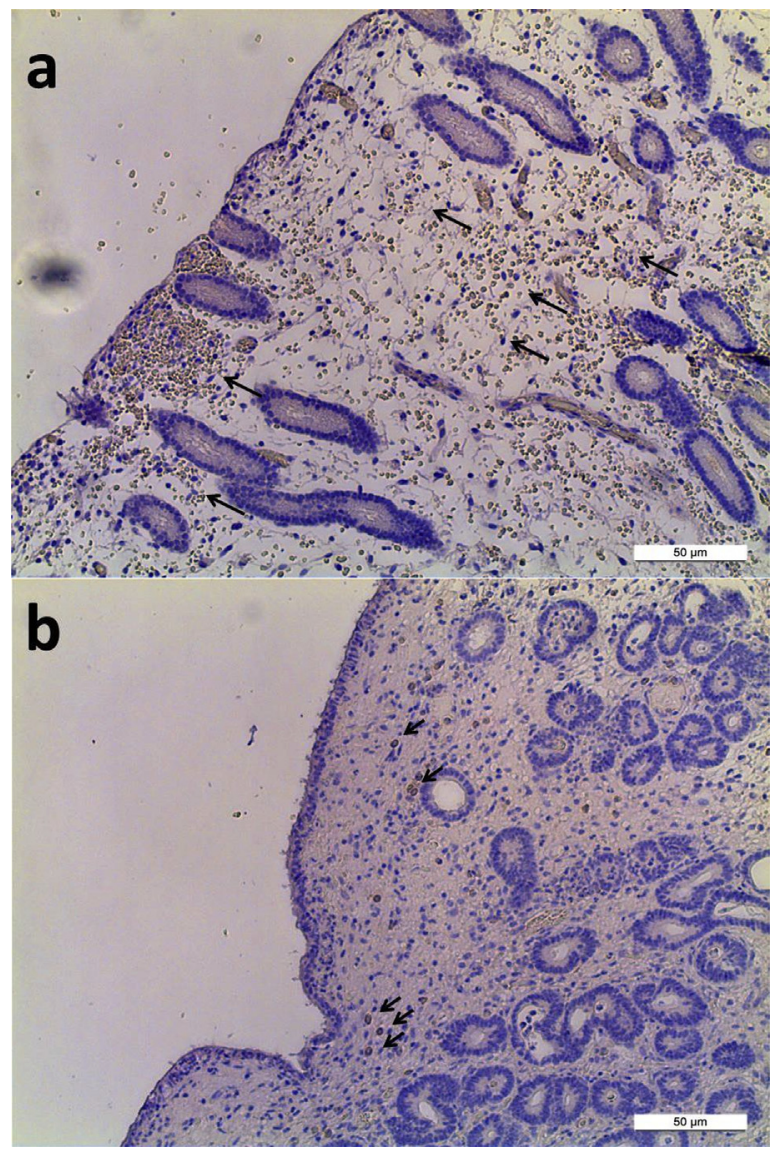

Fig. 5. Representative images of COX-2 immunohistochemical labeling in mares $24 \mathrm{~h}$ after artificial insemination in the (a) control group and (b) the treated group. 
important role in the synthesis of prostaglandins (PGF2 $\alpha$ ) from arachidonic acid, the latter is released by damaged tissues [58]. COX-2 also modulates the endometrium PGF2 $\alpha$ expression and is correlated with luteolysis during late dioestrus [58]. In situations where endometrial inflammation is exacerbated, an increase in PGF2 $\alpha$ synthesis may cause premature luteolysis and embryonic loss [59]. Furthermore, studies that applied exogenous PGF2 $\alpha$ during the periovulatory and early postovulatory period showed a negative effect on luteal function, which also resulted in decreased levels of progesterone [60] and a decreased pregnancy rate [61] in mares.

Despite the observation that PRP was able to reduce COX-2 expression in the endometrium of susceptible mares treated both prior or after AI, the group that was treated post-AI did not show any decreases in the influx of PMNs to the endometrium. Vilés et al. [38] also showed similar results in jennies inseminated with frozen semen and seminal plasma, where a reduction in COX-2 expression also was not observed with a decrease in PMNs migration to the endometrium. Additionally, has been reported increase in jenny fertility after associating seminal plasma to post-thawed semen [62]. This may be due to that neutrophils are already present in the uterine lumen 30 min after insemination [63]; thus, PRP works by inhibiting NF- $\kappa \mathrm{B}[29,30]$ and decreasing inflammation $[52,53,57]$ without causing a sudden reduction in the concentration of neutrophils already present.

Decreased inflammatory response observed in PRP treated mares may helped increase fertility in this groups. In this study, the conception rates of $31 \%$ and $64 \%$ were found for PMIE mares in the control and treated groups, respectively. This demonstrates a significant increase in the conception rates of susceptible mares treated with intrauterine PRP infusion, even though the treated groups were combined in spite of large numerical pregnancy differences among the control and treated groups. Metcalf et al. [43] also observed a similar increase in fertility rates of barren mares after PRP treatment before AI. Others studies using immunomodulatory therapies, such as glucocorticoids $[13,27,28]$, mycobacterium cell wall extract [14], and Propionibacterium acnes [64] also showed an increase in fertility rates among susceptible mares, and was also associated with at downregulation of the inflammatory response, supporting our results. One advantage of the PRP treatment is that it is safer, lower cost, and causes no side effects when compared with other immunomodulatory therapies.

In conclusion, both proposed treatments with PRP were able to reduce the uterine inflammatory process in PMIE mares after breeding. Similar responses were observed between treated groups, including an increase in conception rate of these animals.

\section{Acknowledgments}

The authors thank the São Paulo Research Foundation, grant 2015/00150-8, for financial support.

\section{References}

[1] Gonshor A. Technique for producing platelet-rich plasma and platelet concentrate: background and process. Int J Periodontics Restor Dent 2002;22: 547-57.

[2] Kevy SV, Jacobson MS. Comparision of methods for point of care preparation of autologous platelet gel. J Extra Corpor Technol 2004;36:28-35.

[3] Mazzocca AD, McCarthy MBR, Intravia J, Beitzel K, Apostolakos J, Cote MP et al. An in vitro evaluation of the anti-inflammatory effects of platelet-rich plasma, ketorolac, and methylprednisolone. J Arthrosc Relat Surg 2013;29: 675-83.

[4] Kim HJ, Yeom JS, Koh YG, Yeo JE, Kang KT, Kang YM, et al. Antiinflammatory effect of platelet-rich plasma on nucleus pulposus cells with response of TNF-a and IL-1. J Orthop Res 2014;32:551-6.

[5] El-Sharkawy H, Kantarci A, Deady J, Hasturk H, Liu H, Alshahat M, et al Platelet-rich plasma: growth factors and anti-inflammatory properties.
J Periodontol 2007;78:661-9.

[6] Alam R, Forsythe PA, Lett-Brown MA, Grant JA. Interleukin-8 and RANTES inhibit basophil histamine release induced with monocyte chemotatic and activating factor/monocyte chemoattractant peptide-1 and histamine releasing factor. Am J Respir Cell Mol Biol 1992;7:427-33.

[7] Metcalf ES, Scoggin K, Troedsson MHT. The effect of platelet-rich plasma on endometrial pro-inflamatory cytokines in susceptible mares following semen deposition (Abstract). J Equine Vet Sci 2012;32:498.

[8] Reghini MFS, Ramires Neto C, Segabinazzi LG, Castro Chaves MMB Dell'aqua CPF, Bussiere MCC, et al. Inflammatory response in chronic degenerative endometritis mares treated with platelet-rich plasma. Theriogenology 2016;86:516-22.

[9] Troedsson MHT, Liu IKM, Crabo BG. Sperm transport and survival in the mare. Theriogenology 1998;49:905-15.

[10] Troedsson MHT, Loset K, Alghamdi AM, Dahms B, Crabo BG. Interaction between equine semen and the endometrium: the inflammatory response to semen. Anim. Reprod. Sci 2001;68:273-8.

[11] Zent W, Troedsson M, Xue J-L. Postbreeding uterine fluid accumulation in a normal population of thoroughbred mares: a field study. Proc Am Assoc Equine Pract 1998:64-5.

[12] Morel MCGD. Equine reproductive physiology, breedind and study management. 2 ed. Oxon: CAB International; 2003. p. 287.

[13] Bucca S, Carli A, Buckley T, Dolci G, Fogarty U. The use of dexamethasone administered to mares at breeding time in the modulation of persistent mating induced endometritis. Theriogenology 2008;70:1093-100.

[14] Fumuso EA, Giguire S, Wade J, Rogan D, Videla-Dorna I, Bowden RA. Endometrial IL-1beta, IL-6 and TNF-alpha, mRNA expression in mares resistant or susceptible to postbreeding endometritis. Effects of estrous cycle, artificial insemination and immunomodulation. Vet Immunol Immunopathol 2003:96(1-2):31-41.

[15] Fumuso EA, Aguilar J, Giguire S, Rivulgo M, Wade J, Rogan D. Immune parameters in mares resistant and susceptible to persistent post-breeding endometritis: effects of immunomodulation. Vet Immunol Immunopathol 2007:118(1-2):30-9.

[16] Kaplanski G, Marin V, Montero-Julian F, Mantovani A, Franarier C. IL-6: a regulator of the transition from neutrophil to monocyte recruitment during inflammation. Trends Immunol 2003:2:25-9.

[17] Christoffersen M, Woodward EM, Bojesen AM, Petersen MR, Squires EL, LehnJensen $\mathrm{H}$, et al. Effect of immunomodulatory therapy on the endometrial inflammatory response to induced infectious endometritis in susceptible mares. Theriogenology 2012;78:991-1004.

[18] Woodward EM, Christoffersen M, Campos J, Betancourt A, Horohov D, Scoggin KE, et al. Endometrial inflammatory markers of the early immune response in mares susceptible or resistant to persistent breeding-induced endometritis. Reproduction 2013;145:289-96.

[19] Takeda K, Akira S. TRL signaling pathways. Semin Immunol 2004;16:3-9.

[20] Kotilainen T, Hutinen M, Katila T. Sperm induced leukocytosis in the equine uterus. Theriogenology 1994:41:629-36.

[21] Troedsson MH. Uterine response to semen deposition in the mare. Proc Soc Theriogenol 1995:130-5.

[22] Christoffersen M, Baagoe CD, Jacobsen S, Bojesen AM, Petersen MR, LehnJensen $\mathrm{H}$. Evaluation of the systemic acute phase response and endometrial gene expression of serum amyloid A and pro- and anti-inflammatory cytokines in mares with experimentally induced endometritis. Vet Immunol Immunop 2010:138:95-105.

[23] Nash DM, Sheldon IM, Herath S, Lane EA. Markers of the uterine innate immune response of the mare. Anim Reprod Sci 2010;119:31-9.

[24] Girling JE, Hedger MP. Toll-like receptors in the gonads and reproductive tract: emerging roles in reproductive physiology and pathology. Immunol Cell Biol 2007;85:481-9.

[25] Tizard IR. Innate immunity: the recognition of invaders. In: Tizard I.R. Veterinary immunology. 8 Ed.vol. 2. Rio de Janeiro: Elsevier; 2008. p. 11-27.

[26] Barañao R. Citoquinas en el proceso reproductivo. Reprod Argent 1997;1: $13-27$

[27] Dell' Aqua JA, Papa FO, Lopes MD, Alvarenga MA, Macedo LP, Melo CM. Modulation of acute uterine inflammatory response after artificial insemination with equine frozen semen. Anim Reprod Sci 2006;94:270-3.

[28] Papa FO, Dell'aqua Jr JA, Alvarenga MA, Melo CM, Soares ZF, Lopes MD. Use of corticosteroid therapy on the modulation of uterine inflammatory response in mares after artificial insemination with frozen semen. Pferdeheilkunde 2008;24:79-82.

[29] Bendinelli P, Matteucci E, Dogliotti G, Corsi MM, Banfi G, Maroni P, et al Molecular basis of anti-inflammatory action of platelet-rich plasma on human chondrocytes: mechanisms of NF-kappaB inhibition via HGF. J Cell Physiol 2010;225:757-66.

[30] Van Buul GM, Koevoet WL, Kops N, Bos PK, Verhaar JA, Weinans H, et al. Platelet-rich plasma releasate inhibits inflammatory processes in osteoarthritic chondrocytes. Am J Sports Med 2011;39:2362-70.

[31] Brook D. Uterine cytology. In: McKINNON AO, VOSS JL, editors. Equine reproduction. Philadelphia: Lea \& Febiger; 1993. p. 246-53.

[32] Mccue PM, Scoggin CF, Lindholm AFG. Estrus. In: McKinnon AO, Squires EL, Vaala WE, Vrner DD, editors. Equine reproduction. 2 Ed., vol. 179. Ames: Blackwell Publishing: 2011. p. 1716-27.

[33] McCarrel T, Fortier L. Temporal growth factor release from platelet-rich plasma, trehalose lyophilized platelets, and bone marrow aspirate and their 
effect on tendon and ligament gene expression. J Orthop Res 2009;27: 1033-42.

[34] Alvarenga MA, Iwana De Matos MC. Utilização da escova ginecológica cytobrush na coleta de material endometrial de éguas. Arq Bras Med Vet Zootec $1990 ; 42: 67-8$

[35] Walter I, Handler J, Reifinger M, Aurich C. Association of endometrosis in horses with differentiation of periglandular myofibroblasts and changes of extracellular matrix. Reproduction 2001;121:581-6.

[36] Ricketts SW. Endometrial biopsy as a guide to diagnosis of endometrial pathology in the mare. J Reprod Fertil Suppl 1975;23:341-5.

[37] Rogan D, Fumuso E, Rodriguez E, Wade J, Sanchez Bruni SF. Use of a mycobacterial cell wall extract (MCWE) in susceptible mares to clear experimentally induced endometritis with Streptococcus zooepidemicus. J Equine Veterinary Sci 2007;27:112-27.

[38] Vilés K, Rabanal R, Rodriguez-Prado M, Miró J. Influence of seminal plasma on leucocyte migration and amount of COX-2 protein in the jenny endometrium after insemination with frozen-thawed sêmen. Anim Reprod Sci 2013;143: $57-63$.

[39] Bardagí M, Fondevila D, Ferrer L. Immunohistochemical detection of COX-2 in feline and canine actinic keratoses and cutaneous squamous cell Carcinoma. J Comp Pathol 2012;146:11-7.

[40] Jiwakanon J, Persson E, Berg M, Dalin A. Influence of seminal plasma, spermatozoa and semen extender on cytokine expression in the porcine endometrium after insemination. Anim Reprod Sci 2011;123:210-20.

[41] Anitua E, Andia I, Ardanza B, Nurden P, Nurden AT. Autologous platelet source of proteins for healing and tissue regeneration. Thromb Haemost 2004;91: 4-15.

[42] Marx RE. Platelet-rich plasma (PRP): what is PRP and what is not PRP? Implant Dent 2001;10:225-8.

[43] Metcalf ES. The effect of Platelet-Rich Plasma (PRP) on intraluminal fluid and pregnancy rates in mares susceptible to Persistent Mating-Induced Endometritis (PMIE). J Equine Vet Sci 2014;34:128.

[44] Troedsson MHT, Liu IKM, Ing M, Pascoe J, Thurmond MJ. Multiple site electromyographic recordings of uterine activity following an intrauterine bacterial challenge in mares susceptible and resistant to chronic uterine infection. J Reprod Fertil 1993;99:307-13.

[45] Leblanc MM, Neuwirth L, Jones L, Cage C, Mauragis D. Differences in uterine position of reproductively normal mares and those with delayed uterine clearance detected by scintigraphy. Theriogenology 1998;50:49-54.

[46] Reitzenstein M, Callhan MA, Hansen PJ, Leblanc MM. Aberrations in uterine contractile patterns in mares with delayed uterine clearance after administration of detomidine and oxytocin. Theriogenology 2002;58:887-98.

[47] Schanabel LV, Mohammed HO, Miller BJ, Mcdermott WG, Jacobson MS, Santangelo KS, et al. Platelet rich plasma (PRP) enhances anabolic gene expression patterns in flexor digitorum superficialis tendons. J. Orthop Res 2007:230-40.

[48] Textor JA, Norris JW, Tablin F. Effects of preparation method, shear force, and exposure to collagen on release of growth factors from equine platelet-rich plasma. Am J Vet Res 2011;72:271-8.

[49] Katila T. Sperm-uterine interactions: a review. Anim Reprod Sci 2001;68: 267-72.

[50] Vandaele H, Daels P, Piepers S, LeBlanc MM. The effect of post-insemination dexamethasone treatment on pregnancy rates in mares. Anim. Reprod. Sci 2010;121(Suppl.):110-2.

[51] McDonnell AM, Watson ED. The effects of dexamethasone sodium phosphate on mares with experimentally-induced endometritis. Equi Vet Sci 1993;13: 202-6.

[52] Perkins ND. Post-translational modifications regulating the activity and function of the nuclear factor kappa B pathway. Oncogene 2006;25:6717-30.

[53] Ghosh S, Hayden MS. New regulators of NF-kB in inflammation. Nat Rev Immunol 2008;8:837-48.

[54] Woodall Jr J, Tucci M, Mishra A, Asfour A, Benghuzzi H. Cellular effects of platelet rich plasma interleukin1 release from PRP treated macrophages. Biomed Sci Instrum 2008;44:489-94.

[55] Woodell-May J, Matuska A, Oyster M, Welch Z, O’shaughnessey K, Hoeppner J. Autologous protein solution inhibits MMP-13 production by IL-1b and TNF-a stimulated human articular chondrocytes. J Orthop Res 2011;29:1320-6.

[56] Sundman EA, Cole AJ, Karas V, Vale CD, Tetreault MW, Mohammed HO, et al. The anti-inflammatory and matrix restorative mechanisms of platelet-rich plasma in osteoarthritis. Am J Sports Med 2013;42:35-41.

[57] Ulivi V, Giannoni P, Gentili C, Cancedda R, Descalzi F, p38/NF-kB-dependent expression of COX-2 during differentiation and inflammatory response of chondrocytes. J Cell Biochem 2008;104:1393-406.

[58] Boerboom D, Brown KA, Vaillancourt D, Poitas P, Goff AK, Watanabe K. Expression of key prostaglandin synthases in equine endometrium during late diestrus and early pregnancy. Biol Reprod 2004;70:391-9.

[59] Neely DP, Kindahl H, Stabenfeldt GH, Edqvist LE, Hughes JP. Prostaglandin release patterns in the mare: physiological, pathophysiological, and therapeutic responses. J Reprod Fertil Suppl 1979;27:181-9.

[60] Troedsson MH, Ababneh MM, Ohlgren AF, Madill S, Vetscher N, Gregas M. Effect of periovulatory prostaglandin F2alpha on pregnancy rates and luteal function in the mare. Theriogenology 2001;55:1891-9.

[61] Nie GJ, Johnson KE, Wenzel JG, Braden TD. Effect of administering oxytocin or cloprostenol in the periovulatory period on pregnancy outcome and luteal function in mares. Theriogenology 2003:60:1111-8.

[62] Rota A, Panzani D, Sabatini C, Camillo F. Donkey jack (Equus asinus) semen cryopreservation: studies of seminal parameters, post breeding inflammatory response, and fertility in donkey jennies. Theriogenology 2012;78:1846-54.

[63] Katila T. Onset and duration of uterine inflammatory response of mares afte insemination with fresh semen. Biology reproduction monograph 1. Equine Reproduction VI. Ann Arbor (MI): Society for the Study of Reproduction, Inc Edward Brothers, Inc; 1995. p. 515-7.

[64] Rohrbach BW, Sheerin PC, Cantrell CK, Matthews PM, Steiner JV, Dodds LE. Effect of adjunctive treatment with intravenously administered Propionibacterium acnes on reproductive performance in mares with persisten endometritis. J Am Vet Med Assoc 2007;231:107-13. 